\title{
Studies on dyeing and bacterial resistance of Dacryodes macrophylla extract on woollen fabric
}

\author{
Alvine Sandrine Ndinchout \\ Department of Biochemistry, University of Yaoundé I, Cameroon \\ D. P. Chattopadhyay* \\ Department of Textile Chemistry, Faculty of Technology and Engineering, The Maharaja \\ Sayajirao University of Baroda, Vadodara- 390001 (Gujarat), India \\ Moundipa Fewou Paul \\ Department of Biochemistry, University of Yaoundé I, Cameroon \\ Nyegue Maximilienne Ascension \\ Department of Biochemistry, University of Yaoundé I, Cameroon \\ Varinder Kaur \\ Department of Chemistry, Guru Nanak Dev University, Amritsar-143005 (Punjab), India \\ Sukhraj Kaur
}

Department of Microbiology, Guru Nanak Dev University, Amritsar-143005 (Punjab), India

${ }^{*}$ Corresponding author. E-mail: dpchat6@gmail.com

\begin{abstract}
The dyeing of wool fabric using a natural dye extracted from Dacryodes macrophylla has been studied using both conventional as well as ultrasonic dyeing methods. Natural dye was extracted using water as solvent by Soxhlet extraction method. The extracted color was characterized by spectroscopic studies like UV/Visible and further tested for antimicrobial activity (against Vibrio cholerae (MTCC3906), Salmonella enterica serotype typhi (MTCC733), Shigella flexneri (MTCC1457), Escherichia coli (MTCC119), Listeria monocytogenes (MTCC657) and Staphylococcus aureus (MTCC 96). It was observed that the water extract of $D$. macrophylla showed antimicrobial activities against $S$. enterica. The effect of mordants on the dyeing outcome in terms of colour depth as well as fastness properties of the dyeing was investigated. It has been found that employing all the three techniques of dyeing i.e., conventional dyeing at $100{ }^{\circ} \mathrm{C}$ and $80^{\circ} \mathrm{C}$ as well as ultrasonicated dyeings conducted at $80^{\circ} \mathrm{C}$, the mordanted samples were deeper in depth than their unmordanted counterparts. The results of fastness properties of the dyed fabrics were fair to good. Depths of the shade and fastness properties in case of ultrasonic dyeing were found to be better compared to conventional dyeing. Dacryodes macrophyllaextract was found to enhance microbial resistance of wool as well as was itself as a good source of coloration. These textiles dyed with the natural dyes can be very useful in developing clothing for infants, elderly and infirm people to protect them against common infections.
\end{abstract}

Keywords: Antimicrobial activity; Cotton; Fastness properties; Ultrasonic dyeing; Wool.

\section{INTRODUCTION}

Dyes can generally be described as colored substances which can impart color to a specific substrate to which they are being applied by selective absorption of light (Gürses et al., 2016). They can be classified in two classes synthetic and natural (Kirk-Othmer, 2009). Natural dyes were very popular since primitive ages. However, their use has reduced to a large extent after the arrival of synthetic dyes. Realization of detrimental effects like carcinogenicity, allergenicity, non- biodegradability etc. of many natural dyes, the use of natural dyes has once again gained interest (Susan, 1982; Ratna Padhi, 2019; Melgoza et al., 2004). The plant world provides a huge resource of natural colors which can be acquired from various

\section{Article Info}

DOI: 10.31018/jans.v11i1.1993

Received: January 16, 2019

Revised: February 24, 2019

Accepted: February 28, 2019

\section{How to Cite}

Ndinchout, A. S. et al. (2019). Studies on dyeing and bacterial resistance of Dacryodes macrophylla extract on woollen fabric. Journal of Applied and Natural Science, 11(1): $205-210$ 
Equatorial Guinea and Gabon. In Cameroon it is found in evergreen forest and here and there in semi-deciduous forest and up to $20 \mathrm{~m}$ high and $90 \mathrm{~cm}$ in diameter. It is a fruit tree that blooms in March - August and produces fruits in June - September (Eyog Matig et al., 2006). When ripe, the fruits are fleshy, black and contain a single seed resembling to cherries. The only part of $D$. macrophylla known to use is the pulp contained in the fruit. This very juicy pulp is consumed directly and used in making juices. During consumption, these fruit leaves a dark blackish colour on fingers and garment. This observation means that D. Macrophylla fruits must be a good source of natural dye with probably good wash fatness on textile materials (Ahmad et al., 2011).

But $D$. macrophylla have not yet been investigated with reference as a potential source of natural dye. Nevertheless, (Nolé1 et al., 2017) showed that crude organic extract of these fruits could have anti-obesity/overweight and antioxidant properties. Therefore, the present work was aimed at extracting of natural colour from D. macrophylla fruits using water as solvent medium and examining its dyeability on wool as a substrate. To achieve this goal, soxhlet extraction from the crude dye was performed using water as a solvent and evaluation of its dyeability and fastness was determined after optimizing the dyeing process. The effect of different types of mordants (Kaur et al., 2014) on the dyeing performance was also studied. Finally, the dyeing performance was compared using conventional and ultrasonic dyeing methods. The dye extract was characterized by UV/Visible and the antimicrobial activity (Bala, et al., 2017) of the dye against a number of microbes was also determined. To extract dye from Dacryodes macrophylla and applicability of the dye on textiles and its response to antibacterial activity.

\section{MATERIALS AND METHODS}

Sample of dye: Fruits of Dacryodes macrophylla used for dye extraction were purchased from Nvog-Atangbala market in Yaounde, Cameroon, Center Region and were tested by the National Herbarium of Cameroon in comparison with specimen $N^{\circ} 64991 / \mathrm{HNC}$.

Fabric: Scoured and bleached wool twill (2/2) fabric was procured from Madan Textiles, Amritsar and used for dyeing. This RFD (Ready for Dyeing) woollen fabric was having 145 GSM (grams per square meter).

Mordants: Alum, Copper Sulphate and Ferrous Sulphate of AR grade (Merck) were used as mordants without further purification.

Microbial indicator strains: Different pathogenic bacterial indicator strains employed in this experiment were Vibrio cholerae (MTCC 3906), Salmonella enterica serotype typhi (MTCC 733), Shigella flexneri (MTCC 1457), Escherichia coli (MTCC
119), Listeria monocytogenes (MTCC 657) and Staphylococcus aureus (MTCC 96). The bacterial cultures are procured from Microbial Type Culture Collection, Institute of Microbial Technology, Chandigarh and cultured in Brain Heart Infusion (BHI) broth (HiMedia laboratories, Mumbai, India) under aerobic conditions at $37^{\circ} \mathrm{C}$. The pathogenic yeast Candida spp. is procured from the Department of Microbiology, Government Medical College, Amritsar. It was cultured in Sabouroud dextrose broth of HiMedia under aerobic environment at $37{ }^{\circ} \mathrm{C}$. Microbial cultures were preserved at -80 ${ }^{\circ} \mathrm{C}$ in broth containing $20 \%$ glycerol (HiMedia) and subcultured twice before using them in the experiments.

Extraction of dye: A weighted amount of D. macrophylla powder is introduced into the thimble of the soxhlet extractor and extraction is performed several times using water as solvent. The extracts thus prepared are recovered and kept in the fridge for the subsequent experiments

Preparation of the fabric: The scouring of fabric was conducted using $5 \mathrm{gL}^{-1}$ soap (SDC, Bradford) at $50{ }^{\circ} \mathrm{C}$ for 30 min maintaining $40: 1$ liquor to material ratio. The sample was subsequently washed thoroughly in tap water and dried in air at atmospheric conditions.

Mordanting: Alum, Copper Sulphate and Ferrous Sulphate were used as mordant and premordanting technique were employed. Wool was treated with a solution (5.0\% owf) of an appropriate mordant at material to liquor ratio of $1: 30$, for 30 min. Mordanting in case of alum and copper sulphate was conducted at $80{ }^{\circ} \mathrm{C}$, whereas in case of ferrous sulphate the process was conducted at room temperature. After mordanting the samples were rinsed in cold water to remove the excess of mordant and the samples were subsequently taken for dyeing

Dyeing: The pre-mordanted fabrics samples was dyed (4\% shade) using a constant temperature beaker dyeing machine. The dyeing was also performed at $80^{\circ} \mathrm{C}$ for one hour using 1:30 material to liquor ratio. The dyed samples were rinsed in cold water and dried in open air.

To examine the effect of ultrasonic dyeing the dyeing was also performed using an ultrasonicator (Ellma Transsonic Digital S, $40 \mathrm{KHz}$ ) was employed. Dyeing was conducted both with and without mordants at $80{ }^{\circ} \mathrm{C}$ keeping other detail same as conventional dyeing. Ultrasonic dyeing method was conducted with a probe Sonicator (Model PKS-500F, PCi analytics), containing probe radius $6.5 \mathrm{~mm}$, working at $20 \mathrm{KHz}$ with a maximum power output $500 \mathrm{~W}$ at require temperature. The electronic absorption spectra were recorded using Shimadzu Corp uv-1800 spectrophotometer.

Fastness testing and colorimetric evaluation: A standard ISO C06 C2S test method (Bradford: SDC, 1990) was used to evaluate the color fast- 
ness to washing of dyed samples. For this purpose, the non-ionic detergent $\left(4 \mathrm{gL}^{-1}\right)$ and sodium perborate $\left(1 \mathrm{gL}^{-1}\right)$ were used. Twenty-five steel balls were also used in this test and the experiment was conducted at $\mathrm{pH} 10.5$. The dyed samples were cut into standard size specifications of $10 \times 4 \mathrm{~cm}$. These strips were sewn through the small end to SDC's multifibre test fabric and then washed in the prepared test solution at $60{ }^{\circ} \mathrm{C}$ for $30 \mathrm{~min}$. The experiment was conducted on a Washtec machine (R B E Company, Mumbai, India). The samples were finally cleaned with normal water, dried and examined for color change as well as staining. Rubbing fastness of the dyed samples was determined according to IS-766-88 test on crock meter. The light fastness of the dyed samples was determined on a xenon arc lamp according to ISO 105/B02 using blue wool reference illustrations.

The colorimetric values of the dyeings were determined using a Spectraflash 600 colorimeter (Datacolor International) with $D_{65}$ illumination and 10ºbserver (CIELAB 1976 colour space).

Antimicrobial activity examination: The antimicrobial activities of the water extract of the sample are determined by using well diffusion assay (Reinheimer et al., 1990). The microbial indicator strains are grown in their respective media at $37^{\circ}$ C till the absorbance at the wavelength $580 \mathrm{~nm}$ is 0.2 . Hundred microlitres of the cultures were then spread onto $\mathrm{BHI}$-agar plates and the wells of diameter 6 millimetres were cut onto the agar plates by means of cork borer. Afterward, $100 \mu \mathrm{l}$ of two different concentrations $(1 \mathrm{mg} / \mathrm{ml}$ and $0.5 \mathrm{mg} / \mathrm{ml}$ ) of the crude dye extract dissolved in sterile triple distilled water were introduced into the wells. The plates were placed at 4 degree centigrade for $4 \mathrm{~h}$ to permit diffusion of the samples in the agar media and thereafter incubated at $37^{\circ} \mathrm{C}$ for overnight. The diameter of zone of inhibition is measured in $\mathrm{mm}$. The experiment is performed in triplicates and the standard deviation is calculated.

\section{RESULTS AND DISCUSSION}

Absorption spectra of dye extract in acidic and alkaline pH: The visible spectrum of the aqueous solution of the dye at different $\mathrm{pH}$ values is shown in Figure 1. The $I_{\max }$ of the dye solution in the visible region was found to be at around $400 \mathrm{~nm}$. The dye exhibited a broad and complex absorption indicating it to be a mixture of various phenolic acids (Prasad et al., 2017). At pH 11, the $I_{\max }$ observed a slight red-shift and the color of the dye solution deepens. This may be owing to the ionization of the hydroxyl groups in the alkaline medium (Mahmoud et al., 2007). However, the pH sensitivity at high $\mathrm{pH}$ did not matter as the dyeing were conducted in the lower $\mathrm{pH}$ range.

Effect of application of the dye on wool : Table 1 shows the result of K/S values of the dyed wool

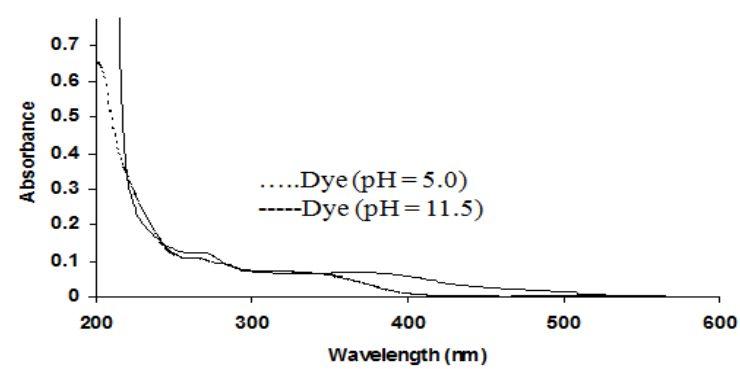

Fig. 1. Visible spectra of extracted dye from Dacryodes macrophylla at different $\mathrm{pH}$ values.
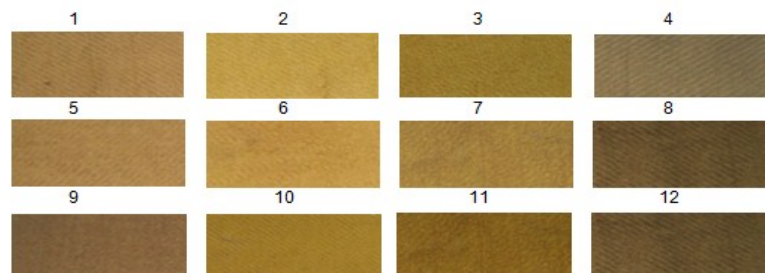

Fig 2. Actual image of the dyed samples (the sample number indicates the conditions given in Table 1).

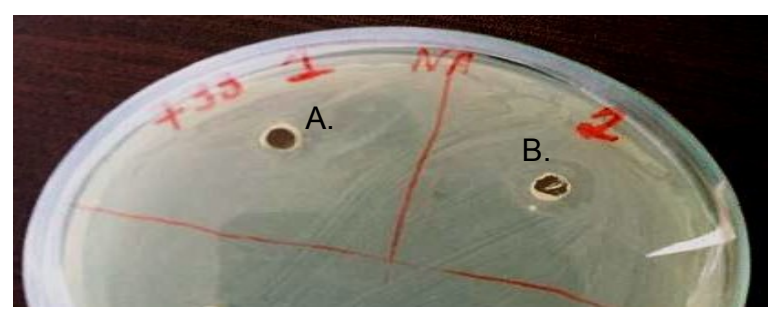

Fig 3. BHl-agar plate showing zones of inhibition; $A$ ) $0.5 \mathrm{mg} / \mathrm{ml}$ water extract, B) $1 \mathrm{mg} / \mathrm{ml}$ water extract against S. enterica.

samples using both conventional and ultrasonic technique of dyeing using different mordants. In contrast to conventional technique of dyeing, the ultrasonication method poses excellent potential in industrial application in terms of reduction of cost, time and energy (Khatri et al., 2011). Dyeing performed at boil resulted higher colour depth than dyeing at $80{ }^{\circ} \mathrm{C}$. Ultrasonic dyeing could not perform better for this particular dye on wool. Application of mordants improved the dye uptake (Haar, et al., 2013). Among the three mordants copper sulphate and ferrous sulphate produced darker shades and from the actual images (Fig 2) of the dyed sample it can be seen that there was variation of tones for different mordants. The maximum $\mathrm{K} / \mathrm{S}$ value has been observed in case of conventional dyeing (boil) on mordanted samples with copper sulphate (14.2) and ferrous sulphate (14.7). On the other side, in case of conventional dyeing $\left(80{ }^{\circ} \mathrm{C}\right)$ without mordants, the $\mathrm{K} / \mathrm{S}$ value is only 3.9 whereas this value is increased up to 5.2 in case of ultrasonicated dyeing $\left(80^{\circ} \mathrm{C}\right)$ technique. It is a clear indication that the ultrasonication facilitates the dye uptake on the woollen samples.

Table 2 shows the fastness properties of dyed samples. The fastness properties are satisfactory. Wash fastness staining results were found to ex- 
Ndinchout, A. S. et al. / J. Appl. \& Nat. Sci. 11(1): 205 - 210 (2019)

Table 1. K/S values of the wool samples dyed using conventional and ultrasonic techniques and different mordants.

\begin{tabular}{llll}
\hline Sample & Dyeing method & Mordant & K/S \\
\hline 1. & Conventional dyeing (boil) & Nil & 6.2 \\
2. & Conventional dyeing (boil) & Alum & 7.3 \\
3. & Conventional dyeing (boil) & Copper sulphate & 14.2 \\
4. & Conventional dyeing (boil) & Ferrous sulphate & 14.7 \\
5. & Conventional dyeing $\left(80^{\circ} \mathrm{C}\right)$ & Nil & 3.9 \\
6. & Conventional dyeing $\left(80^{\circ} \mathrm{C}\right)$ & Alum & 7.2 \\
7. & Conventional dyeing $\left(80^{\circ} \mathrm{C}\right)$ & Copper sulphate & 13.2 \\
8. & Conventional dyeing $\left(80^{\circ} \mathrm{C}\right)$ & Ferrous sulphate & 8.1 \\
9. & Ultrasonicated dyeing $\left(80^{\circ} \mathrm{C}\right)$ & Nil & 5.2 \\
10. & Ultrasonicated dyeing $\left(80^{\circ} \mathrm{C}\right)$ & Alum & 7.4 \\
11. & Ultrasonicated dyeing $\left(80^{\circ} \mathrm{C}\right)$ & Copper sulphate & 8.6 \\
12. & Ultrasonicated dyeing $\left(80^{\circ} \mathrm{C}\right)$ & Ferrous sulphate & 7.1 \\
\hline
\end{tabular}

Table 2. Different fastness ratings ${ }^{a}$ of the dye on wool samples.

\begin{tabular}{|c|c|c|c|c|c|c|c|c|c|c|c|c|}
\hline \multirow[t]{3}{*}{ Sample } & \multirow{3}{*}{$\begin{array}{l}\text { Color } \\
\text { fastness }\end{array}$} & \multicolumn{6}{|c|}{ Color stainingc } & \multirow{3}{*}{$\begin{array}{l}\text { Light } \\
\text { fastness }\end{array}$} & \multicolumn{4}{|c|}{ Rubbing fastness } \\
\hline & & SCA & BUC & $\mathbf{N}$ & $\mathbf{P}$ & $\mathbf{A}$ & WW & & $\begin{array}{l}\text { Color } \\
\text { ness }\end{array}$ & fast- & $\begin{array}{l}\text { Color } \\
\text { ing }\end{array}$ & stain- \\
\hline & & & & & & & & & Dry & Wet & Dry & Wet \\
\hline 1 & $3-4$ & 4 & $4-5$ & $4-5$ & 5 & $4-5$ & $4-5$ & 4 & $4-5$ & 5 & 4 & $4-5$ \\
\hline 2 & 4 & $4-5$ & $4-5$ & $4-5$ & $4-5$ & $4-5$ & 4 & 5 & $3-4$ & $4-5$ & $2-3$ & 4 \\
\hline 3 & $2-3$ & $4-5$ & 4 & $4-5$ & $4-5$ & $4-5$ & 4 & 5 & $3-4$ & $4-5$ & $2-3$ & 4 \\
\hline 4 & 2 & $4-5$ & 4 & $4-5$ & $4-5$ & $4-5$ & 4 & 5 & 4 & $4-5$ & $2-3$ & $3-4$ \\
\hline 5 & 3 & 5 & $4-5$ & $4-5$ & 5 & $4-5$ & 5 & $3-4$ & $2-3$ & 3 & 4 & 4 \\
\hline 6 & 3 & $4-5$ & $4-5$ & $4-5$ & $4-5$ & $4-5$ & $4-5$ & 5 & $2-3$ & 3 & 3 & 4 \\
\hline 7 & 2 & $4-5$ & $4-5$ & $4-5$ & 5 & $4-5$ & $4-5$ & 5 & 3 & $3-4$ & $2-3$ & 5 \\
\hline 8 & 3 & $4-5$ & $4-5$ & 5 & 5 & 4 & 5 & 5 & 4 & $4-5$ & 3 & $3-4$ \\
\hline 9 & 3 & $4-5$ & $4-5$ & $4-5$ & 5 & $4-5$ & 5 & 4 & $3-4$ & 4 & 4 & 5 \\
\hline 10 & 3 & $4-5$ & $4-5$ & $4-5$ & 5 & $4-5$ & 3 & 5 & 3 & 3 & 3 & 5 \\
\hline 11 & 2 & $4-5$ & $4-5$ & $4-5$ & $4-5$ & 4 & $4-5$ & 5 & 4 & $4-5$ & $3-4$ & 4 \\
\hline 12 & 3 & $4-5$ & $3-4$ & $4-5$ & $4-5$ & $4-5$ & $4-5$ & 5 & 3 & $4-5$ & 3 & 4 \\
\hline
\end{tabular}

${ }^{a}$ Grey scale ratings ${ }^{b}$ see Table 1 for dyeing methods ${ }^{c}$ Colour staining rating: SCA, secondary cellulose acetate; $B U C$, bleached unmercerised cotton; $N$, nylon 66; $P$, polyester; $A$, acrylic; $W W$, worsted wool

Table 3. Colorimetric data for wool dyed with fractionated extract of $D$. macrophylla fruits.

\begin{tabular}{llllll}
\hline $\begin{array}{l}\text { Sample } \\
\text { Code }\end{array}$ & $\boldsymbol{L}^{*}$ & $\boldsymbol{a}^{*}$ & $\boldsymbol{b}^{*}$ & $\boldsymbol{c}^{*}$ & $\boldsymbol{h}$ \\
\hline 1 & 64.2 & 5.2 & 34.6 & 24.2 & 80.8 \\
2 & 51.3 & 4.4 & 54.3 & 46.2 & 75.7 \\
3 & 56.2 & 6.3 & 41.9 & 40.5 & 76.1 \\
4 & 43.3 & 4.3 & 28.2 & 14.7 & 79.3 \\
5 & 53.6 & 5.2 & 21.5 & 21.6 & 78.2 \\
6 & 60.1 & 4.4 & 38.2 & 32.3 & 79.8 \\
7 & 58.6 & 3.2 & 40.0 & 23.5 & 82.2 \\
8 & 50.2 & 4.2 & 20.6 & 21.2 & 82.6 \\
9 & 57.2 & 4.1 & 38.5 & 25.1 & 80.9 \\
10 & 62.1 & 1.2 & 43.7 & 40.2 & 87.3 \\
11 & 52.1 & 1.9 & 33.4 & 35.1 & 86.3 \\
12 & 48.8 & 1.0 & 19.9 & 19.0 & 85.4 \\
\hline
\end{tabular}

cellent. The rubbing fastnesses of dyed samples were quite good whereas light fastnesses were moderate.

The mordanting with alum was found to enhance the fastness to light as well as washing but caused dulling of the shade.

The colorimetric data of the dyed wool samples is presented in Table 3. It can be seen that the dye-
Table 4. Antimicrobial activity of water extract of sample.

\begin{tabular}{lll}
\hline & \multicolumn{2}{l}{ Zone of inhibition (in mm) } \\
\cline { 2 - 3 } Indicator strains & $\begin{array}{l}\text { Water extract } \\
(\mathbf{m g} / \mathbf{m l})\end{array}$ & $\begin{array}{l}\text { Water ex- } \\
\text { tract } \mathbf{0 . 5 m g /} \\
\mathbf{m l})\end{array}$ \\
\hline S. enteric & $11 \pm 0.9$ & $9 \pm 0.7$ \\
V. cholerae & $-^{*}$ & - \\
E. coli & - & - \\
S. aureus & - & - \\
Candida spp. & - & - \\
Sh. Flexneri & - & - \\
L. monocytogenes & - & - \\
\hline
\end{tabular}

*- No zone of inhibition was observed

ing of wool using fractionated extract of $D$. macrophylla fruits were brownish yellow in hue (as noticed from the lower $a^{*}$ and higher $h$ values). Dyed samples were duller, especially the unmordanted as well as the samples mordanted with ferrous sulphate in comparison to the dyed samples mordanted with alum and copper sulphate (as seen from the lower $c^{*}$ values of the specified dyeing). These results may be attributed to the presence of yellow flavonoids (quercetin and quercitrin) in the 
extract used in this study.

It has been found that employing all the three techniques of dyeing i.e., conventional dyeing at $100{ }^{\circ} \mathrm{C}$ and $80{ }^{\circ} \mathrm{C}$ as well as ultrasonicated dyeings conducted at $80{ }^{\circ} \mathrm{C}$, the mordanted samples were deeper in depth than their unmordanted counterparts.

Antimicrobial activity: The antimicrobial activity of the crude dye extract was determined by using well diffusion assay. The water extract of dye showed antimicrobial activities against $S$. enterica at both the concentrations (Table 4; Fig....). However, the extract had no antimicrobial activity against any other microbial indicator strains.

The antimicrobial properties of the water extract of $D$. macrophylla could be due to the presence of polyphenols in the extract. Plant-derived polyphenols are known to have various properties such as antioxidant, anti-inflammatory, anticancer and antimicrobial (Daglia, 2012). Antimicrobial properties of polyphenols are probably due to their hydrophobic character that helps them to interact with the lipid bi-layer cell membrane of the pathogens and destabilize it (Xu et al., 2014) leading to leakage of cellular contents.

\section{Conclusion}

Fractionated extract of $D$. macrophylla berries can be used successfully as a source of natural dye for dyeing of wool; the dye appears to behave as a mordant dye with optimum uptake occurring under the conditions used. Mordanting improved the fastness properties as well as amends the depth of shade and other colorimetric parameters such as chroma, lightness as well as color, this being attributable to the formation of dye-mordant complex. Ultrasonication offers advantage of conducting dyeings at low temperature $\left(80{ }^{\circ} \mathrm{C}\right)$. Wash fastness staining results ranges from 3- 4, were found to excellent. The rubbing fastnesses with rating 4-5 and 5 of dyed samples were quite good whereas light fastnesses were moderate. The fractionated extract of $D$. macrophylla berries selectively inhibited the growth of $S$. enterica, in a dose-dependent manner as the extract at the dose of 1.0 and $0.5 \mathrm{mg} / \mathrm{ml}$ showed 11 and $9.0 \mathrm{~mm}$ of zones of inhibitions, respectively. The results of effective antimicrobial activity and good fastness properties of dyed wool showed that these berries may find potential application in the field of potential medical textiles.

\section{ACKNOWLEDGEMENTS}

We thankfully acknowledge the financial support in the form of fellowship and cooperation in each step of this doctoral research provided by the Organization for Women in Science for Developing World, Italy and Swedish International Development Corporation Agency which helped the authors to complete the work.

\section{REFERENCES}

1. Ahmad, W. Y. W., Rahim, R., Ahmad, M. R., Abdul Kadir, M. I., Misnon, M. I. (2011). The Application of Gluta Aptera Wood (Rengas) as natural dye on Silk and Cotton Fabrics. Universal J Environ Res Technol. 1(4): 545-551.

2. Bala, R., Behal, J., Kaur, V., Jain, S. K., Rani, R., Manhas, R. K., Prakash, V. (2017). Sonochemical synthesis, characterization, antimicrobial activity and textile dyeing behaviour of nano-sized cobalt(III) complexes. Ultrasonic Sonochemistry. 35(A): 294- 303.

3. Betti, J. L. (2004). An ethnobotanical study of medicinal plants among the Baka Pygmies in the Dja Biosphere Reserve, Cameroon. Afr. Stud. Monogr. 25 (1):1-27

4. Bradford: SDC, (1990). Standard Methods for the Determination of Colour Fastness of Textiles and Leather, $5^{\text {th }}$ Edn. (Bradford: SDC, 1990).

5. CIELAB 1976 colour space $\left(D_{65}\right.$ illuminant, $10^{\circ}$ observer).

6. Daglia, M. (2012). Polyphenols as antimicrobial agents. Current Opinion in Biotechnology. 23(2): 174181.

7. Eyog Matig, O., Ndoye, O., Kengue, et Awono, J., Editeurs, A. (2006) Les Fruitiers Forestiers Comestibles du. Cameroun. Pages: 204 p. (ISBN-13: 978-929043-707-9).

8. Gürses, A., Açıkyıldız, M., Günes, K. and Sadi Gürses, M. (2016). Springer Briefs in Green Chemistry for Sustainability, Dyes and Pigments, 1- 88.

9. Haar, S., Schrader, E., Gatewood, B. M. (2013). Comparison of aluminum mordants on the colorfastness of natural dyes on cotton, Clothing and Textiles Research Journal. 31(2); 97-108.

10.Kaur,V., Chattopadhyay, D. P., Kaur, S. (2014). Studies on the Effect of Mordants on Dyeing Behaviour of Bamboo Fibres using Natural Dyes. International Journal of Engineering Innovation and Research (IJEIR). 3(5): 666- 671.

11.Khatri, Z, Memonb/ M. H,, Khatri, A., Tanwari, A. (2011). Cold Pad-Batch dyeing method for cotton fabric dyeing with reactive dyes using ultrasonic energy. Ultrasonics Sonochemistry. 18; 1301-1307.

12.Kirk-Othmer: Dyes natural, Encyclopedia of chemical Technology. Published online: 17th April 2009.

13.Mahmoud, A. S., Ghaly, A. E. and Brooks. S. L. (2007). Influence of Temperature and $\mathrm{pH}$ on the Stability and Colorimetric Measurement of Textile Dyes. American Journal of Biotechnology and Biochemistry. 3 (1): 33-41.

14.Melgoza, R. M. Cruz, A. and Buitron, G. (2004). Anaerobic/aerobic treatment of colorants present in textile effluents. Water Science and Technology. 50 (2): 149- 155.

15.Nolé1, T., Albert, A., Joel Elysée Tsafack, T., Donfagsiteli, N., Yedjou Clement, G., Thiabo Alembert, T., Agbor Gabriel, A., Paul Bernard, T. (2017). Medicinal Uses and Natural Availability of Three Plant Species in Selected Ecosystems in Cameroon. Journal of Analytical \& Pharmaceutical Research, 4(4): 1- 9.

16.Prasad, S., Mandal, I., Singh, S., Paul, A., Mandal, Bh., Venkatramani, R., Swaminathan, R. (2017). Near UV-Visible electronic absorption originating from charged amino acids in a monomeric protein. Chem Sci. 8(8): 5416-5433. 
Ndinchout, A. S. et al. / J. Appl. \& Nat. Sci. 11(1): 205 - 210 (2019)

17.Ratna Padhi, B.S. (2012). Pollution due to synthetic dyes toxicity \& carcinogenicity studies and remediation. International. J. of Environmental Sciences. 3 (3): 940- 955.

18. Record derives from WCSP (in review) (data supplied on 2012-03-23) which reports it as an accepted name with original publication details: Ann. Jard. Bot. Buitenzorg 42: 202 (1932).

19.Reinheimer, J. A., Demkow, M. R., Condioti, M. C. (1990). Inhibition of coliform bacteria by lactic acid bacteria. Australian J. Dairy Technol. 45: 5-9.

20.Susan, C. Druding: Dye History from 2600 BC to the 20th Century, Washington at Convergence, 1982.

21.Xu, C., Yagiz, Y., Hsu, W., Simonne, A., Lu, J., Marshall, M. R. (2014). Antioxidant, Antibacterial, and Antibiofilm Properties of Polyphenols from Muscadine Grape (Vitis rotundifolia Michx.) Pomace against Selected Food borne Pathogens. Journal of Agricultural and Food Chemistry. 62 (28): 6640-6649. 